\title{
PENGARUH UKURAN PERUSAHAAN, LEVERAGE, DAN PROFITABILITAS TERHADAP INCOME SMOOTHING PADA PERUSAHAAN MANUFAKTUR YANG TERDAFTAR DI BURSA EFEK INDONESIA PERIODE 2014-2018
}

\author{
Tri Setyaningsih $^{1}$, Titiek Puji Astuti ${ }^{2}$, Yunus Harjito ${ }^{3}$ \\ Fakultas Ekonomi/Program Studi Akuntansi, Universitas Setia Budi Surakarta \\ ${ }^{1}$ trisetyaningsih242@gmail.com \\ 2 titiekpujiastuti@gmail.com \\ 3yunus.harjito@gmail.com
}

\begin{abstract}
This Study aims to examine the effect of firm size, leverage and profitability on income smoothing of the manufacturers registered at the Indonesia's Stock Exchange in 20142018. Type of research in this study is quantitative research. The data used be in the form of secondary data taken based on the company's financial statements in manufacturing companies listed on Indonesia Stock Exchange in 2014-2018. The sampling technique of this study uses purposive sampling method. The analysis method of this research uses a regression analysis with Eviews 9 Version. Based on the result of analysis data in this research showes that the firm size have a positive effect on income smoothing while the leverage and profitability does not effect on income smoothing in manufacturing companies listed on Indonesia Stock Exchange in 2014-2018.
\end{abstract}

Keywords: Firm Size, Leverage, Profitability, Income Smoothing

\section{PENDAHULUAN}

Informasi mengenai akuntansi yang berhubungan dengan kinerja perusahaan merupakan kebutuhan mendasar pada proses pengambilan keputusan bagi investor di pasar modal. Sumber informasi yang tersebut adalah laporan keuangan.Laporan keuangan merupakan sarana pengkomunikasian dan sebagai sumber informasi atas kondisi keuangan utama dari suatu perusahaan yang diperlukan untuk memenuhi kebutuhan berbagai pihak, baik internal maupun eksternal perusahaan (Kieso, 2008). Laporan keuangan yang disusun oleh manajemen pun harus mampu memberikan informasi yang relevan bagi para pemakai informasi keuangan dalam rangka pengambilan keputusan ekonomis. Walaupun semua isi dari laporan keuangan bermanfaat bagi para pemakai, namun biasanya perhatian lebih banyak ditujukan pada informasi laba (Pertiwi, 2019).

Perkembangan laba yang dihasilkan perusahaan sangat mempengaruhi masa depan perusahaan, hal ini terlihat dari minat investor terhadap perusahaan dengan tingkat saham yang stabil daripada perusahaan dengan meningkatkan laba yang tinggi. Menurut para investor, perusahaan dengan tingkat laba stabil lebih memberikan jaminan keamanan dalam berinvestasi serta mempunyai masa depan perusahaan yang baik dan kelangsungan hidup perusahaan dalam jangka panjang (Ayunika dan Yadnyana, 2018). Salah satu informasi yang penting untuk pengambilan keputusan yaitu laba. Menyadari hal tersebut, membuat para manajemen cenderung untuk melakukan disfunctional behavior (perilaku tidak semestinya) (Budiasih, 2009).

Bentuk disfunctional behavior yang dilakukan oleh manajemen terhadap laporan keuangan yaitu dengan melakukan manipulasi laba atau manajemen laba (Prabayanti dan Yasa, 2011). Tindakan tersebut dilakukan guna meningkatkan nilai dan kinerja perusahaan agar perusahaan tersebut terlihat baik serta untuk mempengaruhi investor dalam pengambilan 
keputusan dalam menanamkan modalnya. Manipulasi yang sering dilakuakn yaitu income smoothing (perataan laba). Disfunctional behavior pada perataan laba bisa muncul dengan memanfaatkan kecenderungan dari pemakai laporan keuangan yang hanya memperhatikan informasi laba dari pada laba itu berasal (Abiprayu, 2011).

Income smoothing yang dilakukan perusahaan tidak terlepas dari konflik kepentingan antara manajemen dengan pemegang saham yang erat kaitannya dengan teori keagenan (agency theory), dalam teori ini menjelaskan bahwa manajemen memiliki informasi yang lebih detail mengenai perusahaan dibandingkan yang diketahui pihak pemilik saham (principal), hal ini disebut asimetri (assymetry information). Apabila terjadi penyalahgunaan informasi laba yang dilakukan oleh manajemen serta tujuannya hanya untuk kepentingan pihak manajemen dalam mengambil keuntungan finansial, besar kemungkinan dapat mengakibatkan terjadinya praktik income smoothing(Pertiwi, 2019).

Belkaoui, (2007) mendefinisikan bahwa perataan laba merupakan upaya yang dilakukan seacara sengaja untuk memperkecil fluktuasi pada tingkat laba yang dianggap normal bagi perusahaan. Isu perataan laba banyak dibicarakan baik dalam teori maupun dalam penelitian. Perataan laba didorong oleh keinginan untuk mengurangi laba dan menaikkan biaya pada periode berjalan yang dapat mengurangi utang pajak (Dewi dan Prasetiono, 2012). Perataan laba lebih bersifat menutupi informasi yang sebenarnya harus disampaikan, sehingga informasi yang disajikannya tidak mengungkapkan apa yang sebenarnya terjadi. Perataan laba atau income smoothing sebenarnya memperlihatkan bahwa manajer berusaha untuk tidak memberikan informasi ekonomi perusahaan kepada para stakeholder, sehingga investor mungkin tidak memperoleh informasi yang akurat mengenai laba tersebut (Budileksmana dan Andriani, 2005).

\section{Perumusan Masalah}

Berdasarkan latar belakang yang telah dijelaskan, penulis tertarik untuk melakukan penelitian dengan berfokus kepada "Bagaimana Pengaruh Ukuran Perusahaan, Leverage, Dan Profitabilitas Terhadap Income Smoothing Pada Perusahaan Manufaktur Yang Terdaftar Di Bursa Efek Indonesia Periode 2014-2018”.

\section{Tinjauan Pustaka}

Penelitian ini menggunakan teori agensi (agency theory). Teori agensi (agency theory) merupakan suatu pendekatan yang memaparkan konsep manajemen yang terkait dalam pembahasan konsep perataan laba. Teori agensi menyatakan bahwa praktik manajemen laba dipengaruhi oleh adanya konflik kepentingan antara manajemen (agent) dan pemilik (principal) yang muncul ketika setiap pihak berusaha untuk mencapai atau mempertahankan tingkat kemakmuran yang diinginkannya. Teori agensi memiliki asumsi setiap individu memiliki motivasi dari diri sendiri, sehingga menimbulkan adanya konflik kepentingan antara principal maupunagent (Noviana dan Yuyetta, 2011). Anggapan yang mendasari pada teori keagenan adalah bahwa antara agen dengan principal terdapat konflik kepentingan. Teori agensi dipandang sebagai kontrak antara manajemen (sebagai agent) dan pemilik (sebagai principal). Primanita dan Setiono (2006) menyatakan bahwa karakteristik asli dari seseorang akan mengutamakan atau mementingkan kepentingan sendiri, manajemen (agent) tidak selalu bertindak demi kepentingan terbaik pemilik (principal), sehingga manajemen (agent) akan cenderung melakukan perekayasaan atau memanipulasi laba. Salah satu pemanipulasian laba yang dilakukan yaitu perataan laba atau income smoothing.

Perataan laba (income smoothing) merupakan teknik manajemen laba dalam hal perataan atas fluktuasi laba yang dilaporkan yang dianggap normal bagi suatu perusahaan (Noviana dan 
Yuyetta, 2011). Belkaoui (2007) menyatakan bahwa perataan laba didefinisikan sebagai upaya yang dilakukan seacara sengaja untuk dilakukan memperkecil fluktuasi pada tingkat laba yang dianggap normal bagi perusahaan. Menurut Juita dan Susi (2007) laba yang memiliki kualitas tinggi mencerminkan laba yang dapat dipertahankan untuk jangka waktu yang panjang. Untuk dapat mencerminkan hal tersebut, perusahaan melakukan income smoothing, dimana income smoothing merupakan proses manipulasi waktu terjadinya laba secara sukarela yang dilakukan oleh pihak manajemen dengan motivasi tertentu untuk menekan variasi laba, agar laba yang dilaporkan sesuai dengan apa yang dikehendakinya.

\section{Pengembangan Hipotesis \\ Pengaruh Ukuran Perusahaan Terhadap Income Smoothing}

Berdasarkan teori agency bahwa perusahaan yang mempunyai ukuran yang besar memiliki motivasi yang lebih kuat untuk melakukan perataan laba dibandingkan dengan perusahaan yang kecil, karena perusahaan besar mendapatkan pengawasan yang lebih dari investor, sehingga manajer lebih memilih menggunakan metode akuntansi yang menangguhkan laba yang dilaporkan dari periode sekarang ke periode yang akan datang, sehingga dapat memperkecil laba yang dilaporkan. Hal tersebut dilakukan oleh perusahaan untuk menghindari perubahan laba yang terlalu drastis, karena fluktuasi laba yang besar menunjukkan risiko yang besar dalam investasi, sehingga mempengaruhi kepercayaan investor terhadap perusahaan. Dengan demikian bahwa perusahaan yang memiliki ukuran besar maka semakin besar juga kemungkinan manajemen melakukan praktik perataan laba. Penelitian yang dilakukan oleh Arfan dan Wahyuni (2010), Dewi dan Prasetiono (2012), Budiasih (2009), Hastuti (2017), Peranasari dan Dharmadiaksa (2014) menunjukkan bahwa ukuran perusahaan berpengaruh positif terhadap perataan laba, sehingga hipotesis dalam penelitian ini adalah :

H1 : Ukuran perusahaan berpengaruh positif terhadap income smoothing.

\section{Pengaruh Leverage Terhadap Income Smoothing}

Menurut teori agency bahwa manajer memiliki asimetri informasi terhadap pihak eksternal perusahaan seperti kreditor dan investor yang terjadi ketika manajer memiliki informasi internal perusahaan lebih banyak dibandingkan pihak eksternal. Dengan menggunakan asumsi risk averse, maka investor dan kreditor ingin menanamkan modalnya ataupun meminjamkan modalnya bila perusahaan tersebut memiliki rasio leverage yang tinggi. Dengan kondisi tersebut maka manajer dapat menggunakan informasi yang diketahuinya untuk memanipulasi laporan keuangan perusahaan dalam memaksimalkan kesejahteraannya dengan cara melakukan tindakan perataan laba. Dengan kata lain besarnya tingkat utang perusahaan (leverage) dapat mempengaruhi tindakan manajemen dalam melakukan tindakan perataan laba (income smoothing). Hal ini dikarenakan perusahaan yang memiliki tingkat leverage yang tinggi akan diduga melakukan tindakan perataan laba karena perusahaan cenderung terancam default atau teracam gagal, sehingga manajemen akan membuat kebijakan yang dapat meningkatkan pendapatan (Pande dan Suryanawa, 2017).

Penelitian yang dilakukan oleh Ashari,et.al (1994), Pande dan Suryanawa (2017), Pertiwi (2019), Yusuf dan Soraya (2004) menunjukkan bahwa leverage berpengaruh positif terhadap perataan laba, sehingga hipotesis dalam penelitian ini adalah :

$\mathrm{H} 2$ : Leverage berpengaruh positif terhadap income smothing.

\section{Pengaruh Profitabilitas Terhadap Income Smoothing}

Berdasarkan teori agency, profitabilitas menggambarkan adanya perbedaan tujuan yaitu antara principal dan agent, dimana setiap individu ingin melakukan tindakan sesuai dengan keinginannya masing-masing hal tersebut dilakukan guna untuk mensejahterakan dirinya. 
Principal sebagai pemegang saham menginginkan tercapainya tingkat profitabilitas yang tinggi setiap tahunnya guna meningkatkan kekayaanya, sedangkan agen sebagai manajer termotivasi untuk mensejahterakan dirinya guna memenuhi kebutuhan ekonominya dengan cara melakukan income smoothing semestinya. Terjadinya asimetri informasi inilah yang menyebabkan seorang manajer melakukan manipulasi data dalam menyajikan informasi akuntansi sesuai dengan harapan principal, meskipun informasi tersebut tidak menggambarkan kondisi rill perushaan yang sebenarnya. Salah satu teknik yang digunakan oleh manajer yaitu dengan melakukan praktik perataan laba.

Penelitian yang dilakukan Budiasih (2009) menyatakan bahwa variabel profitabilitas berpengaruh terhadap praktik perataan laba, perusahaan yang memiliki profitabilitas tinggi cenderung untuk melakukan perataan laba karena manajemen mengetahui kemampuan perusahaan untuk mendapatkan laba pada masa yang akan datang. Tingkat profitabilitas yang stabil akan memberikan keuntungan bagi para manajemen, misalnya seperti mempertahankan posisi jabatan apabila kinerja diukur dengan tingkat laba yang mampu dihasilkan. Ashari, et.al (1994) menyatakan bahwa rekayasa laba di perusahaan-perusahaan Singapura dipengaruhi oleh profitabilitas, industri, dan nasionalitas. Hal ini menunjukkan adanya pengaruh profitabilitas terhadap perataan laba, hasil ini sama dengan yang ditemukan oleh Carlson dan Chenchuramaiah (1997),Budileksmana dan Andriani (2005), Hastuti (2017), Peranasari dan Dharmadiaksa (2014), Iskandar dan Saurdana (2016), serta Oktyawati dan Agustina (2014) yang menunjukkan bahwa profitabilitas berpengaruh terhadap perataan laba, sehingga dari penjelasan diatas, maka hipotesis yang dapat dirumuskan adalah :

H3 : Profitabilitas berpengaruh positif terhadap income smoothing.

\section{METODE PENELITIAN}

\section{Populasi dan Sampel}

Populasi dalam penelitian ini merupakan perusahaan manufaktur yang terdaftar di Bursa Efek Indonesia (BEI) periode tahun 2014-2018. Sampel yang digunakan dalam penelitian ini didapatkan dengan menggunakan metode purposive sampling. Berdasarkan teknik pengambilan sampel dengan menggunakan metode purposive sampling, maka sampel dalam penelitian ini berjumlah 335 sampel yang diperoleh dari 67 perusahaan selama 5 tahun.

\section{Variabel Penelitian}

\section{Ukuran Perusahaan (X1)}

Menurut Iskandar dan Saurdana (2016) ukuran perusahaan merupakan nilai yang menunjukkan besar kecilnya perusahaan. Terdapat beberapa proksi yang dapat digunakan untuk mewakili ukuran perusahaan yaitu jumlah karyawan, total aktiva, log size, nilai pasar saham, dan lain-lain. Menurut Budiasih, (2009) ukuran perusahaan adalah skala untuk menentukan besar kecilnya perusahaan. Ukuran perusahaan dapat dihitung dengan menggunakan logaritma natural dari total aktiva. Sehingga dapat dirumuskan sebagai berikut:

$$
\text { Size }=\text { Ln total asset }
$$

\section{Leverage (X2)}

Leverage menggunakan rasio total utang terhadap ekuitas (debt equity ratio) membadingkan berapa persentase dana yang disediakan oleh kreditur dengan dana yang disediakan oleh pemilk modal. Perhitungan rasio ini dilakukan dengan menggunakan cara membandingkan antara seluruh utang, termasuk utang lancar dengan seluruh ekuitas. Rasio ini digunakan untuk mengetahui jumlah dana yang disediakan peminjam (kreditor) dengan pemilik perusahaan (Kasmir, 2017). Skala pengukuran yang digunakan adalah sebagai berikut: 


$$
\text { Debt to Equity }=\frac{\text { Total Hutang }}{\text { Total Ekuitas }}
$$

\section{Profitabilitas (X3)}

Profitabilitas perusahaan digunakan untuk melihat kemampuan perusahaan dalam memperoleh laba. Kemampuan perusahaan dalam memperoleh profit yang diukur dengan laba setelah pajak dengan total aktiva (Yusuf dan Soraya, 2004). Profitabilitas di dalam penelitian ini diukur dengan Return On Asset. Rasio ini menggambarkan perbandingan antara laba bersih setelah beban bunga dan pajak dengan total aktiva perusahaan (Hastuti, 2017). Pengukuran profitabilitas yang diproksikan dengan ROA dapat disajikan sebagai berikut:

$$
R O A=\frac{\text { Laba bersih setelah pajak }}{\text { Total aset }}
$$

\section{Income Smoothing (Y)}

Perataan laba atau income smoothing merupakan suatu tindakan yang dilakukan seacara sengaja guna untuk memperkecil fluktuasi pada tingkat laba yang dianggap normal bagi suatu perusahaan (Belkaoui, 2007). Perataan laba diukur dalam Indeks Eckel. Adapun untuk menghitung income smoothing index dapat menggunakan rumus sebagai berikut (Eckel 1981):

$$
\text { Indeks perataan laba }=\frac{\mathrm{CV} \Delta \mathrm{I}}{\mathrm{CV} \Delta \mathrm{S}}
$$

Keterangan:

$\mathrm{CV}=$ Koefisien variasi dari variabel, yaitu standar deviasi dibagi dengan nilai yang diharapkan

$\Delta \mathrm{I}=$ Perubahan laba dalam satu periode

$\Delta \mathrm{S}=$ Perubahan penjualan dalam satu periode

$\mathrm{CV} \Delta \mathrm{S}$ dan $\mathrm{CV} \Delta \mathrm{I}$ dapat dihitung sebagai berikut:

$\mathrm{CV} \Delta \mathrm{S}$ atau $\mathrm{CV} \Delta \mathrm{I}=\sqrt{\frac{\sum(\Delta X-\Delta \bar{X})^{2}}{n-1}}: \Delta X$

Keterangan:

$\Delta X=$ Perubahan laba (I) atau penjualan (S)

$\Delta \bar{X}=$ Rata-rata perubahan laba (I) atau penjualan (S)

$\mathrm{n} \quad=$ Banyaknya tahun yang diamati

Menurut Yusuf dan Soraya (2004) apabila indeks kurang dari satu maka perusahaan diklasisifikasikan melakukan praktik perataan laba (income smoothing) dan apabila indeks lebih dari satu perusahaan diklasisifikasikan tidak melakukan praktik perataan laba (income smoothing).

\section{Teknik Analisis Data}

Penelitian ini dilakukan dengan menggunakan teknik analisis regresi data panel dengan menggunakan software eviews 9.Income smoothing dalam penelitian ini diukur menggunakan indeks eckel. Indeks eckel digunakan untuk mengetahui perusahaan yang melakukan tindakan perataan laba (income smoothing). 


\section{Metode Analisis}

Model penelitian ini menggunakan regresi data panel untuk menguji ukuran perusahaan, leverage, dan profitabilitas terhadap income smoothing. Model persamaan regresi data panel adalah sebagai berikut:

Keterangan:

$$
\mathrm{Y}=\alpha+\beta 1 \mathrm{X} 1+\beta 2 \mathrm{X} 2+\beta 3 \mathrm{X} 3+\varepsilon
$$

$\begin{array}{ll}\mathrm{Y} & : \text { Tindakan peratan laba } \\ \alpha & \text { : konstanta, } \\ \beta 1 \beta 2 \beta 3 & \text { : koefisien regresi, } \\ \mathrm{X} 1 & : \text { Ukuran perusahaan, } \\ \mathrm{X} 2 & \text { : Leverage, } \\ \mathrm{X} 3 & \text { : Profitabilitas, } \\ \varepsilon & \text { : Standar error. }\end{array}$

\section{HASIL DAN PEMBAHASAN}

\subsection{Hasil Penelitian}

\subsubsection{Analisis Statistik Deskriptif}

Tabel 1 Statistik Deskriptif

\begin{tabular}{lcccc}
\hline \multicolumn{1}{c}{ Keterangan } & Minimum & Maksimum & Mean & Std Deviasi \\
\hline Ukuran Perusahaan & 25,61948 & 33,49072 & 28,59868 & 1,601033 \\
Leverage & 0,074316 & 6,340625 & 0,868098 & 0,796882 \\
Profitabilitas & 0,000157 & 0,920997 & 0,087377 & 0,095687 \\
Income Smoothing & 0,001144 & 189,2751 & 5,364056 & 19,49942 \\
\hline
\end{tabular}

Sumber : Data sekunder yang telah diolah

Berdasarkan hasil statistik deskriptif tersebut untuk variabel ukuran perusahaan memiliki nilai minimum sebesar 25,61948 dan nilai maksimum sebesar 33,49072 dan memiliki nilai mean dan standar deviation masing-masing 28,59868 dan 1,601033. Berdasarkan hasil statistik deskriptif tesebut untuk variabel leverage memiliki nilai minimum sebesar 0,074316 dan nilai maksimum sebesar 6,340625 dan memiliki nilai mean dan standar deviation masing-masing 0,868098 dan 0,796882 .

Berdasarkan hasil analisis statistik deskriptif diatas untuk variabel profitabilitas memliki nilai minimum sebesar 0,000157 dan nilai maksimum sebesar 0,920997 dan memiliki nilai mean dan standar deviation masing-masing 0,087377 dan 0,095687. Berdasarkan hasil analisis statistik deskriptif diatas untuk variabel income smoothing memliki nilai minimum sebesar 0,001144 dan nilai maksimum sebesar 189,2751 dan memiliki nilai mean dan standar deviation masing-masing 5,364056 dan 19,49942 .

\subsubsection{Analisis Regresi Data Panel}

Berdasarkan pengujian yang telah dilakukan, maka model regresi data panel yang sesuai dalam penelitian ini yaitu random effect model. Berikut disajikan hasil pengujian random effect model sebagai berikut:

Tabel 2 Hasil Regresi Model Random Effect

\begin{tabular}{llrl}
\hline Variabel & Coefficient & t-statistic & Prob. \\
\hline C & $-55,63359$ & $-2,284534$ & 0,0230 \\
Uk Perusahaan & 2,181444 & 2,548617 & 0,0113
\end{tabular}




\begin{tabular}{llrr} 
Leverage & $-1,873727$ & $-1,145844$ & 0,2527 \\
Profitabilitas & 2,721568 & 0,207388 & 0,8358 \\
\hline R-Squared & & 0,023367 \\
Adjusted R-square & & 0,014515 \\
F-statistik & & 2,639792 \\
Prob (F-statistik) & & 0,049483 \\
\hline \hline
\end{tabular}

Sumber : Data sekunder yang telah diolah

Berdasarkan tabel 2 menunjukkan hasil regresi data panel dengan menggunakan model random effect. Hasil regresi bertujuan untuk mengetahui adanya hubungan antara variabel independen (ukuran perusahaan, leverage, profitabilitas) terhadap variabel dependen (income smoothing).

\subsubsection{Uji Asumsi Klasik}

\section{Uji Normalitas}

Uji normalitas digunakan untuk ukuran sampel yang besar dapat diabaikan atau dengan kata lain tidak perlu dilakukan uji normalitas (Ghozali dan Ratmono, 2013).

\section{Uji Multikolonieritas}

Menurut Ghozali dan Ratmono (2013) uji multikolinearitas bertujuan untuk menguji apakah dalam model regresi ditemukan korelasi yang tinggi atau sempurna antar variabel independen dalam penelitian ini. Menurut Ghozali dan Ratmono (2013) salah satu cara yang digunakan untuk mendeteksi adanya multikolinearitas dengan matriks korelasi yaitu koefisien korelasi kurang dari $90(<0,90)$ maka model bebas dari multikolinearitas. Berikut ini merupakan hasil dari uji multikolinearitas:

\begin{tabular}{lccc}
\multicolumn{4}{c}{ Tabel 3 Uji Multikolinearitas } \\
\hline & Ukuran Perusahaan & Leverage & Profitabilitas \\
\hline Ukuran perusahan & 1,000000 & 0,054067 & 0,182686 \\
Leverage & 0,054067 & 1,000000 & $-0,051816$ \\
Profitabilitas & 0,182686 & $-0,051816$ & 1,000000 \\
\hline
\end{tabular}

Sumber : Data sekunder yang telah diolah

Berdasarkan tabel diatas diketahui bahwa nilai korelasi antar variabel independen kurang dari 0,90 $(<0,90)$, sehingga dapat disimpulkan bahwa tidak terjadi multikolinearitas.

\section{Uji Heteroskedastisitas}

Metode yang digunakan dalam penelitian ini yaitu White Heteroskedasticity Test. Hasil yang diperlukan atau digunakan dari hasil uji heteroskedastisitas ini adalah Obs*Rsquared.dengan hipotesis sebagai berikut:

a. $\mathrm{HO}=$ Tidak ada heteroskedastisitas.

b. $\mathrm{H} 1$ = Ada heteroskedastisitas.

Apabila p-value Obs*R-squared mempunyai nilai probabilitas Chi-square yang signifikan (nilai $\mathrm{p}=0,000$ ). Dengan demikian maka hipotesis alternatif (H1) adanya heteroskedastisitas dalam model tidak dapat ditolak atau dengan kata lain terjadi masalah heteroskedastisitas dalam model regresi (Ghozali dan Ratmono, 2013). Berikut ini merupakan hasil dari uji Heteroskedasticity Test White: 
Tabel 4 Hasil Heteroskedasticity Test:White

\begin{tabular}{lcll}
\hline \multicolumn{4}{l}{ Heteroskedasticity Test: White } \\
\hline F-statitic & 1,046897 & Prob. F (9,325) & 0,4023 \\
Obs*R-squared & 9,438357 & Prob. Chi-square (9) & 0,3978 \\
Scaled explained SS & 217,9353 & Prob. Chi-square (9) & 0,0000 \\
\hline
\end{tabular}

Sumber: Data sekunder yang telah diolah

Berdasarkan hasil heteroskedastisitas test white di atas menunjukkan nilai Obs*Rsquared mempunyai nilai probabilitas Chi-square 0,3978 atau lebih dari 0,05 (> 0,05). Hal tersebut menyatakan bahwa tidak terjadi masalah heteroskedastisitas dalam model regresi.

\section{Uji Autokorelasi}

Uji autokorelasi dilakukan untuk menguji apakah di dalam model regresi linier terdapat korelasi antar kesalahan pengganggu pada periode t dengan kesalahan pada periode t-1 (Ghozali dan Ratmono, 2013). Hasil dari uji autokorelasi dapat dilihat dari nilai Durbin Watson. Apabila Durbin Watson berada pada daerah dU sampai 4-dU dapat disimpulkan bahwa model regresi tidak mengandung autokorelasi. Berikut disajikan gambar uji autokorelasi dengan menggunakan tabel Durbin Watson:

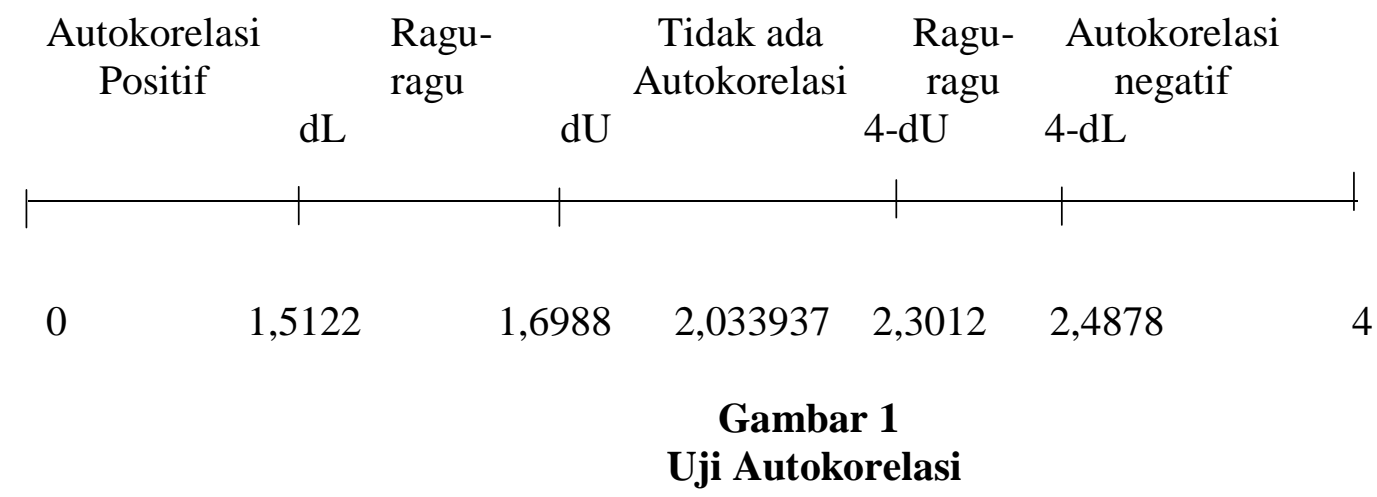

\subsubsection{Pengujian Hipotesis}

\section{Uji statistiK F}

Uji statistik F pada dasarnya dilakukan untuk mengetahui apakah semua variabel independen yang dimasukkan ke dalam model mempunyai pengaruh secara bersama-sama terhadap variabel dependen. Hal tersebut dapat dilakukan dengan membandingkan antara $\mathrm{F}$ hitung dengan $\mathrm{F}$ tabel dengan nilai signifikansi kurang dari 0,05. Berdasarkan tabel 2 diatas, diketahui $\mathrm{F}$ hitung sebesar 2,639792dengan probabilitas (prob F-statistic ) sebesar 0,049483. Probabilitas lebih kecil dari 0,05 sehingga dapat disimpulkan bahwa ukuran perusahaan, leverage, profitabilitas secara simultan berpengaruh terhadap income smoothing(perataan laba).

\section{Uji t}

Hasil uji t menunjukkan bahwa variabel ukuran perusahaan Ukuran perusahaan memiliki $\mathrm{t}$ statistik sebesar 2,548617 dengan nilai probabilitas signifikansi 0,0113. Hal ini menunjukkan bahwa nilai signifikansi lebih kecil dari 0,05 yang berarti ukuran perusahaan berpengaruh positif terhadap income smoothing, maka hipotesis 1 diterima, variabel leverage memiliki $\mathrm{t}$ statistik sebesar-1,145844dengan nilai probabilitas signifikansi 0,2527. Hal ini menunjukkan bahwa nilai signifikansi lebih besar dari 0,05 yang berartileverage tidak berpengaruh terhadap income smoothing, maka hipotesis 2 ditolak, dan untuk variabel profitabilitas memiliki t statistik sebesar 0,207388dengan nilai probabilitas signifikansi 0,8358. Hal ini menunjukkan bahwa nilai 
signifikansi lebih besar dari 0,05 yang berarti profitabilitas tidak berpengaruh terhadap income smoothing, maka hipotesis 3 ditolak. Berikut disajikan hasil dari uji t:

Tabel 5 Hasil Uji Hipotesis

\begin{tabular}{lccc}
\hline \multicolumn{1}{c}{ Variabel } & t-statistic & Signifikan & Keterangan \\
\hline Uk perusahaan & 2,548617 & 0,0113 & Signifikan \\
Leverage & $-1,145844$ & 0,2527 & Tidak signifikan \\
Profitabilitas & 0,207388 & 0,8358 & Tidak signifikan \\
Sumber : Data sekunder yang telah diolah & &
\end{tabular}

Model persamaan regresi data panel yang terbentuk yaitu sebagai berikut:

INCOME SMOOTHING = -55,63359 + 2,181444 UK -1,873727 LEV + 2,721568 PROF + e

\section{Koefisien determinasi $\left(\mathbf{R}^{2}\right)$}

Koefisien determinasi ini menunjukkan kemampuan variabel bebas dalam menjelaskan variabel terkait. Berdasarkan tabel 2 diketahui bahwa Adjusted $R$-squared sebesar 0,014515atau $1,45 \%$. Artinya variabel independen dapat menjelaskan variabel dependen sebesar 1,45\%. Sedangkan $98,55 \%$ dijelaskan oleh faktor lain diluar penelitian ini.

\subsection{Pembahasan}

\section{Pengaruh Ukuran Perusahaan terhadap Income Smoothing}

Hasil pengujian menunjukkan bahwa ukuran perusahaan mempunyai nilai koefisien sebesar 2,181444 dengan nilai signifikansi sebesar 0,0113. Nilai sign probabilitas dari ukuran perusahaan lebih kecil dari $0,05(<0,05)$ maka ukuran perusahaan berpengaruh positif terhadap income smoothing, sehingga hipotesis yang telah dirumuskan (H1) diterima. Hasil penelitian ini sejalan dengan penelitian yang dilakukan oleh Arfan dan Wahyuni (2010), Dewi dan Prasetiono (2012), Budiasih (2009), Hastuti (2017), Peranasari dan Dharmadiaksa (2014) yang menyatakan bahwa ukuran perusahaan berpengaruh positif terhadap income smoothing.

Nilai koefisien probabilitas yang positif menunjukkan bahwa semakin besar suatu perusahaan maka memiliki dorongan untuk melakukan praktik perataan laba dibandingkan dengan perusahaan yang kecil. Hal ini sesuai dengan agency teory bahwa perusahaan yang besar mendapatkan pengawasan yang lebih ketat dari para investor, sehingga manajer lebihmemilih menggunakan metode akuntansi yang menangguhkan laba yang dilaporkan dari periode sekarang ke periode mendatang sehingga dapat memperkecil laba yang akan dilaporkan. Hal tersebut dilakukan oleh perusahaan untuk menghindari perubahan laba yang terlalu drastis,karena kenaikan laba yang drastis akan menyebabkan pajak yang bertambah, dan penurunan laba yang drastis akan menimbulkan image yang kurang baik dimata investor maupun kreditur, karena investor maupun kreditur akan meragukan kemampuan perusahaan tersebut yang memiliki aset atau ukuran perusahaan yang besar tetapi memiliki kemampuan mendapatkan labanya sangat tidak bagus atau tidak stabil, sehingga investor lebih melirik atau memilih pada perusahaan yang besar dan memiliki laba yang stabil, dikarenakan jaminan akan keberlangsungan jangka panjang atas perusahaan tersebut. Investor mencari perusahaan besar karena investor biasanya tidak ingin mengambil risiko untuk berinvestasi ke perusahaan yang masih kecil dan berkembang. Perusahaan besar dianggap sudah memiliki kemampuan yang sangat baik dan pengalaman yang lebih baik sehingga lebih dipercaya. 


\section{Pengaruh Leverage terhadap Income Smoothing}

Hasil pengujian menunjukkan variabel leverage mempunyai nilai koefisien sebesar 1,1873727 dengan nilai signifikansi sebesar 0,2527. Nilai sign probabilitas dari leverage lebih besar dari 0,05, maka leverage tidak berpengaruh terhadap income smoothing. Hipotesis yang telah dirumuskan $(\mathrm{H} 2)$ ditolak.

Hal ini berarti bahwa besar atau kecilnya leverage yang diproksikan dengan DER (debt to equity ratio)yang dimiliki perusahaan tidak mempengaruhi perusahaan untuk melakukan praktik income smoothing, karena perusahaan tersebut mampu membayar hutangnya dengan modal sendiri tanpa menggunakan modal dari investor. Apabila suatu perusahaan mempunyai hutang yang tinggi, maka perusahaan tersebut membayar hutangnya menggunakan laba dari operasional perusahaan, sehingga hal tersebut dapat menyebabkan laba suatu perusahaan menurun secara drastis yang dapat menimbulkan fluktuasi laba.

Namun pasar modal memberikan kemudahan dalam memfasilitasi pembayaran hutang perusahaan, dimana perusahaan publik di Bursa Efek Indonesia saat ini mendapat kemudahan pinjaman efek dari PT Kliring dan penjaminan Efek di Indonesia dibawah pengawasan Bapepam. Sehingga dengan diberikan kemudahan suatu perusahaan dalam pembayaran hutang maka besar atau kecilnya hutang tidak mempengaruhi manajemen untuk melakukan tindakan income smoothing. Hasil penelitian ini sejalan dengan penelitian yang dilakukan oleh Arfan dan Wahyuni (2010), Suryandari (2012), serta Ginantra dan Putra (2015) yang menyatakan bahwa leverage tidak berpengaruh terhadap income smoothing.

\section{Pengaruh Profitabilitas terhadap Income Smoothing}

Hasil pengujian diketahui bahwa variabel profitabilitas mempunyai nilai koefisien sebesar 2,721568 dengan nilai signifikansi sebesar 0,8358. Nilai sign probabilitas lebih besar dari 0,05, maka profitabilitastidak berpengaruh terhadap income smoothing, sehinggahipotesis yang telah dirumuskan (H3) ditolak.

Hal ini menunjukkan bahwa tinggi atau rendahnya profitabilitas suatu perusahaan tidak mempengaruhi perusahaan untuk melakukan tindakan income smoothing, karena ketika seorang investor akan berinvestasi maka akan melihat profitabilitas dari perusahaan tersebut, apabila perusahaan tersebut memiliki laba yang terlalu tinggi maka terdapat indikasi bahwa perusahaan tersebut melakukan tindakan income smoothing. Namun investor juga melihat arus kas dari perusahaan tersebut dalam menilai kinerja suatu perusahaan dibandingkan dengan laba yang dilaporkan dari perusahaan.

Menurut Bernstein (1993) mengemukakan bahwa kas memberikan likuiditas dan fleksibilitas yang besar. Analisis laporan keuangan mengakui bahwa analisis arus kas merupakan pengukuran yang valid dibandingkan analisis laba yang dilaporkan, shingga tinggi atau rendahnya profitabilitas tidak mempengaruhi pihak manajemen untuk melakukan tindakan income smoothing. Alasan lain tidak berpengaruhnya profitabilitas terhadap praktik perataan laba diduga karena investor cenderung mengabaikkan informasi ROA yang ada secara maksimal (Juniarti, dan Corolina 2005). Hal ini menyebabkan manajemen tidak termotivasi melakukan perataan laba Hasil penelitian ini mendukung hasil penelitian yang dilakukan oleh Noviana dan Yuyetta (2011), Rustam dan Hastuti (2012), Ginantra dan Putra (2015), serta Santoso dan Salim (2012) yang menyatakan bahwa profitabilitas tidak berpengaruh terhadap income smoothing.

\section{KESIMPULAN}

Penelitian ini menggunakan pendekatan kuantitatif dengan data sekunder yang diperoleh dari data perusahaan manufaktur yang terdaftar di Bursa Efek Indonesia (BEI) periode 20142018. Penelitian ini bertujuan untuk menguji pengaruh variabel ukuran perusahaan, leverage, dan profitabilitas terhadap income smoothing. Analisis data dalam penelitian ini menggunakan 
regresi data panel dengan program eviews 9. Berdasarkan hasil analisis data dan pembahasan yang telah disajikan dalam bab sebelumnya, maka dapat ditarik kesimpulan bahwa Ukuran Perusahaan berpengaruh positif terhadap income smoothing pada perusahaan manufaktur yang terdaftar di Bursa Efek Indonesia (BEI) periode 2014-2018. Leverage tidak berpengaruh terhadap income smoothing pada perusahaan manufaktur yang terdaftar di Bursa Efek Indonesia (BEI) periode 2014-2018, Profitabilitas tidak berpengaruh terhadap income smoothing pada perusahaan manufaktur yang terdaftar di Bursa Efek Indonesia (BEI) periode 2014-2018.

Penelitian ini masih terdapat beberapa keterbatasan yang perlu diperhatikan oleh peneliti selanjutnya. Beberapa keterbatasan dalam penelitian ini yaitu antara lain: yang pertama penelitian ini menggunakan variabel ukuran perusahaan, leverage, dan profitabilitas, tetapi hanya variabel ukuran perusahaan yang berpengaruh terhadap income smoothingdari tiga variabel yang mempengaruhi income smoothing, kedua hasil penelitian ini tidak dapat digeneralisasikan, karena penelitian ini tidak dilakukan pada seluruh perusahaan yang terdaftar di Bursa Efek Indobesia, tetapi hanya dilakukan pada perusahaan manufaktur yang terdaftar di BEI.

Berdasarkan keterbatasan penelitian ini, maka perlu dilakukan adanya penyempurnaan penelitian untuk selanjutnya. Adapun saran untuk peneliti selanjutnya yaitu: Bagi peneliti selanjutnya disarankan untuk menggunakan variabel moderasi, seperti kepemilikan manajerial, karena dengan adanya kepemilikan manajerial maka manajer akan mengontrol tindakan yang dapat merugikan dirinya sendiri. Penelitian selanjutnya disarankan untuk menambah sampel perusahaan dengan menggunakan seluruh perusahaan yang terdaftar di Bursa Efek Indonesia.

\section{DAFTAR PUSTAKA}

Abiprayu, K. B. (2011). Pengaruh Profitabilitas, Ukuran Perusahaan, Financial Leverage, Kualitas Audit, dan Dividen Payout Ratio Terhadap Peratan Laba (Studi Kasus pada Perusahaan Manufaktur yang Terdaftar di Bursa Efek Indonesia Tahun 2006-2009). Skripsi. Fakultas Ekonomi Universtas Diponegoro.

Arfan, M dan Wahyuni, D. (2010). Pengaruh Firm Size, Winner/Loser Stock, dan Debt To EquityRatio Terhadap Perataan Laba (Studi pada Perusahaan Manufaktur yang Terdaftar di Bursa Efek Indonesia). Jurnal Telaah \& Riset Akuntansi.

Ashari, N., Koh, H. C., Tan, S. L. dan Wang. W.H. (1994). Factor Affecting Income Smoothing Among Listed Companies in Singapore. Accounting Business Research, Vol 24 (96).

Ayunika, N. P. N dan Yadnyana, I. K. (2011). Pengaruh Ukuran Perusahaan, Profitabilitasdan Financial Leverage terhadap Praktik Perataan Laba pada Perusahaan Manufaktur. E-Jurnal Akuntansi Universitas Udayana.

Belkaoui, A. R. (2007). Teori Akuntansi edition Kelima (Krista Ali Akbar Yulianto, penerjemah). Jakarta : Salemba Empat.

Bernstein, L. (1993). Financial Statement Analysis. Homewood, IL: Irwin.

Budiasih, I. (2009). Faktor-Faktor yang Mempengaruhi Praktik Perataan Laba.Jurnal Ilmiah Akuntansi dan bisnis. 
Budileksmana, A dan Andriani, E. (2005). Faktor-faktor yang Mempengaruhi Praktik Perataan Laba pada Perusahaan - perusahaan di Bursa Efek Jakarta. Jurnal Akuntansi dan Investasi Vol 6 (1).

Carlson, Steven, J, dan T. B. Chenchuramaiah. (1997). Ownership Differences and Firms Income Smoothing Behavior. Journal of Business Finance \& Accounting.

Dewi, K. S dan Prasetiono. (2012). Analisis Pengaruh ROA, NPM, DER, dan SizeTerhadap Praktik Perataan Laba. Diponegoro Journal Of Management Volume 1, Nomor 2, Tahun 2012, Halaman 172-180.

Eckel, Norm. (1981). The Income Smoothing Hypothesis Revisited. ABACUS.

Ginantra, dan Putra. (2015). Pengaruh Profitabilitas, Leverage, Ukuran Perusahaan, Kepemilikan Publik, Dividend Payout Ratio dan Net Profit Margin pada Perataan Laba. E-Jurnal Akuntansi Universitas Udayana.

Ghozali, dan Ratmono. (2013). Analisis Multivariat dan Ekonometrika Teori, Konsep, dan Aplikasi dengan Eviews 8. Semarang: Badan Penerbit Universitas Diponegoro.

Hastuti, R. T. (2017). Faktor yang Mempengaruhi Income Smoothing pada Perusahaan Manufaktur di BEI Tahun 2013-2015. Jurnal Ekonomi.Vol 22 (3).

Iskandar, A. F dan Saurdana, K. A. (2016). Pengaruh Ukuran Perusahaan, Return On Asset, dan Winner/Loser Stock Terhadap Praktik Perataan Laba. E-Jurnal AkuntansiUniversitas Udayana.

Juita, D. S dan Susi. (2007). Pengaruh Adanya Praktik Income Smoothing Serta Tingkat Hutang Terhadap Return Saham Perusahaan-Perusahaan Industri Barang Konsumsi dan Aneka Industri di Bursa Efek Jakarta Periode 2001-2006. Aksioma: Jurnal Riset Akuntansi.

Juniarti dan Corolina. (2005). Analisa Faktor Faktor yang Berpengaruh terhadap Perataan Laba (Income Smoothing) pada Perusahaan-Perusahaan Go Public. Jurnal Akuntansi \& Keuangan Vol 7 (2).

Kasmir. (2017). Analisis Laporan Keuangan. Jakarta: PT Rajagrafindo Persada.

Kieso. (2008). Akuntansi Intermediate. Edisi keduabelas. Jakarta: Erlangga.

Noviana, S.R dan Yuyetta, E.N.A. (2011). Analisis Faktor-Faktor Yang Mempengaruhi Praktik Perataan Laba (Studi Empiris Perusahaan Manufaktur Yang Terdaftar Di BEI Periode 2006-2010). Jurnal Akuntansi \&Auditing Vol. 8 (1).

Oktyawati, D dan Agustina, D. (2014). Pengaruh Profitabilitas, Leverage, dan Nilai Perusahaan Terhadap Income Smoothing dan Return Saham pada Perusahaan Manufaktur yang Terdaftar di Bursa Efek Indonesia (BEI). Jurnal Akuntansi \& Auditing. Vol. 10 (2).

Pande dan Suryanawa. (2017). Pengaruh Leverage Pada Perataan Laba Dengan Good Corporate Governance Sebagai Variabel Pemoderasi. E-Jurnal Akuntansi Universitas Udayana. 
Pertiwi, L. (2019). Pengaruh Ukuran Perusahaan, Debt To Equity Ratio dan Net Profit Margin Terhadap Income Smoothing pada Perusahaan Manufaktur yang Terdaftar Di Bursa Efek Indonesia. Skripsi. Fakultas Ekonomi dan Bisnis Universitas Muhammadiyah Sumatera Medan.

Peranasari dan Dharmadiaksa. (2014). Perilaku Income Smoothing, dan Faktor-Faktor yang Memengaruhinya.

Prabayanti, dan Yasa, G. W. (2011). Perataan Laba (Income Smoothing) dan Analisis FaktorFaktor yang Mempengaruhinya (Studi Pada Perusahaan Manufaktur yang Terdaftar di Bursa Efek Indonesia). Jurnal Akuntansi Universitas Udayana.

Primanita dan Setiono. (2006). Manajemen Laba: Konsep, Bukti, Empiris dan Implilkasinya. Sinergi Kajian Bisnis dan Manajemen.

Santoso, dan Salim. (2012). Pengaruh Profitabilitas, Financial Leverage, Dividen, Ukuran Perusahaan, Kepemilikan Institusioanal, dan kelompok Usaha terhadap Peratan Laba. Confference in Bussines, Accounting and Management.

Suryandari. (2012). Analisis Faktor-Faktor Yang Mempengaruhi Income Smoothing. Media Komunikasi FIS. Universitas Mahasaraswati Denpasar.

www.idx.co.id

Yusuf, M dan Soraya. (2004). Faktor-faktor yang Mempengaruhi Praktik Perataan Laba pada Perusahaan Asing dan Non Asing di Indonesia. Jurnal Akuntansi dan Auditing Indonesia. Vol. 8 (1). 